\title{
jako konieczne, czyli \\ literaturoznawcza nie-pewność
}

\section{Recenzja książki Edwarda Balcerzana Literackość. Modele, gradacje, eksperymenty, WN UMK, Toruń 2013, ss. 462.}

W kategoriach dialektycznych, mamy tu przykład przejścia ilości w jakość, pracowitego zbierania informacji, które może doprowadzić do powstania nowej teorii dotyczącej całości.

\section{[W. Golding, Ruchomy cel] ${ }^{1}$}

Współczesnego odbiorcę tekstów teoretycznoliterackich tytuł książki Edwarda Balcerzana może zaskakiwać. Wszak już piętnaście lat wcześniej Jonathan Culler, uznając w swej Teorii literatury próby określenia granic literatury i sprecyzowania pojęcia literackości za daremne - daremne znaczy tu, że nie istnieje możliwość wykładni pewnej, bezdyskusyjnej, możliwej do przyjęcia przez ogół osób parających się teorią - sformułował kontrowersyjne pytanie: „a do czego nam taka definicja jest potrzebna?”. Zasugerował też, iż możemy się bez niej doskonale obyć; mamy zresztą jej pragmatyczny, i niezmiernie skuteczny w praktyce, wymiennik - literaturą jest to, co ogół zajmujących się tą sferą rzeczywistości za literaturę uważa. Sama zaś literackość dowodził badacz - nie jest dziś najważniejszym problemem definicyjnym, przed którym stoimy, o ile w ogóle jest ona problemem ${ }^{2}$. Po wygłoszeniu owych dość bezceremonialnych tez Culler dokonał swoistej teoretycznej wolty - przeszedłszy na pozycje rzecznika badań etycznych, przeniósł kategorię literackości na samą teorię, a demarkacyjny problem wyjściowy ostatecznie zdeprecjonował:

${ }^{*}$ Uniwersytet im. Adama Mickiewicza, Wydział Filologii Polskiej i Klasycznej, Zakład Historii Literatury XX wieku, Teorii Literatury i Sztuki Przekładu, e-mail: lapsang3@ amu.edu.pl.

${ }^{1}$ W. Golding, Ruchomy cel, przeł. K. Majchrzak, Rebis, Poznań 1997, s. 61.

${ }^{2}$ Zob. J. Culler, Co to jest literatura i czy pytanie to ma jakiekolwiek znaczenie?, [w:] tenże, Teoria literatury, przeł. M. Bassaj, Prószyński i Spółka, Warszawa 1998. 
przemawia [do mnie] metafora teorii jako przestrzeni dyskursywnej, w której znajdują się dziś badania literackie i kulturowe, nawet jeśli udaje nam się o tym zapominać, jak zapominamy o powietrzu, którym oddychamy. [...] książki poświęcone teorii obywają się dziś bez definicji własnego przedmiotu - wychodząc z niewątpliwie słusznego założenia, że ludzie zainteresowani książką o teorii mają jakieś pojęcie, czym ona jest [...]. Teorii zarzuca się [...], że odciąga studentów od literatury i wartości literackich. Zarzut ten nie jest do końca bezpodstawny, ponieważ czasu zawsze brakuje, a czytający Foucaulta, Derridę, Lacana i Butler mają go jeszcze mniej dla Ashberego i Zukofskiego, by nie wspomnieć o Dickensie i Thackeray'u. [...] W rozważaniach nad rolą literatury w teorii [...] wprowadzam teorię do literatury i uwypuklam to, co literackie w teorii, zamiast utrzymywać między nimi bezpieczny dystans ${ }^{3}$.

A przecież, mimo iż Leopold Staff zalecał swym czytelnikom, by zaczęli budowanie od dymu z komina, pytanie fundamentalne, czyli pytanie o fundament, nigdy nie utraciło swej mocy, zaś wiersz Staffa nie może być instrukcją dla architekta. To jeden z powodów ważności tematyki podjętej przez Balcerzana, który zastanawia się, na podstawie czego zdefiniowana została dyscyplina zwana literaturoznawstwem. Drugi powód wynika z faktu, że po okresie dominacji badań traktujących tekst jako ilustrację tez zewnętrznych wobec literatury obserwujemy powrót do immanencji dzieła artystycznego i stare pytania na powrót stają w awangardzie rozważań teoretycznych, domagając się nowych rozpoznań.

Zacznijmy lekturę książki od, skrywającego w sobie dwie możliwości, czy może lepiej powiedzieć dwie strategie lekturowe, podtytułu. Dzięki niemu czytelnik dokonuje wstępnego rozpoznania i rozumienia całości. Może zatem wskazuje on, że porządek teoretyczny tekstu przebiega od siły (model) ku słabości (eksperyment), a autor buduje (chce zbudować) w nas przekonanie, że materia tekstów artystycznych rozsadzi najdoskonalszą teorię, na co melancholijnie powinniśmy przystać? Może jednak myśl porządkująca biegnie odwrotnie? Od zrozumienia naszej poznawczej słabości (model), które to rozpoznanie staje się źródłem nowych procesów poznawczych (eksperyment)? Wpatrzeni w przemijające postacie nauki, budujemy wstępne i jednocześnie słabe modele, by, przeprowadzając eksperyment, sól naszej wiedzy o świecie, stworzyć nowe postacie naukowych rozpoznań, wolnych od dogmatyzmu i wiecznie otwartych na nigdy niegotowe i niewyczerpywalne dzieła sztuki? Z całą pewnością - ale to wiadomo dopiero po skończonej lekturze - dla Balcerzana napięcie wynikające ze styku sprzecznych elementów jest wartościowsze niż pojedyncza możliwość. Niemniej, postawione pytanie pozostaje, zwłaszcza że 7. teza traktatu Ludwiga Wittgensteina, przytoczona na początku omawianej tu pracy (s. 13: „O czym nie można mówić, o tym trzeba milczeć"), złączona z przekonaniem Wiktora Szkłowskiego (s. 13: „wiedza o literackości literatury uobecnia się w sposób na wpół zrozumiały, a jeżeli bywa werbalizowana, to prowizorycznie

${ }^{3}$ Tenże, Literatura w teorii, przeł. M. Maryl, Universitas, Kraków 2013, s. 11-14. 
i nieostatecznie, intuicyjnie, półświadomie") wskazuje, że pewność czynionych przez Balcerzana rozważań podszyta jest ich ontyczną wręcz niepewnością.

W Punkcie wyjścia (rozdział poprzedza motto zaczerpnięte z powieści Stanisława Lema, wskazujące na brak ustaleń prymarnych w humanistyce) Balcerzan, pytając o związek pomiędzy literackością i literaturą, wskazuje na cztery impulsy literackości: formalno-językowy, emocjonalny, ideologiczny oraz badawczy. Zostawmy na boku pytanie, czy są to impulsy, które generuje rzeczywistość, my zaś jesteśmy jedynie ich sejsmografem; czy przeciwnie, to my (Balcerzan) wysyłamy je w świat, jako ich podmiotowe źródło. Przyjrzyjmy się poczynionym tu rozważaniom, wychodząc od pytania o kompletność tej propozycji. Gdyby chcieć uzupełnić powyższy szereg, można by zaproponować dwa kolejne impulsy: pragmatyczny oraz magiczny. Czy dopełniałyby one zarysowaną panoramę czy, przeciwnie, burzyły uzyskany obraz?

Wydaje się, że Balcerzan chce pokazać kolejno następujące uwikłania literackości oraz literatury: antynomiczne, utożsamiające, dopełniające oraz uwielokrotniające. A zatem słowo wprzęgnięte w literaturę byłoby jednocześnie modyfikowane obiektywnymi ponadjednostkowymi regułami języka, naszym prywatnym uczuciowym idiolektem, narzucanymi nam światopoglądami i ich słownikami oraz, płynącą z rozpoznań naukowych, multiplikacją semantyczną wypowiedzi wyprowadzanej z doświadczenia w stronę laboratorium. Impuls magiczny, polegający na przekonaniu, iż w literackości skrywa się coś metafizycznego, radykalnie odmiennego od tego, co nas otacza, wskazywałby na inność dzieła artystycznego, niepodobnego do „zwyczajnych" komunikatów; pragmatyczność z kolei, ujęłaby te myśli o literaturze, które wiążą ze sobą człowieka-świat-tekst, wpisane w przestrzeń przyjemności z jednej, uprawianego zawodu, z jego intelektualno-społeczną powinnością, z drugiej strony. Kontekst ludzki jest tu o tyle istotny, że rozbraja postawione wyżej podstawowe pytanie, nawet wątpliwość, czy mamy przed sobą impulsy pewne, wynikające $\mathrm{z}$ faktu "auktorialnego" obserwowania rzeczywistości, czy przeciwnie, zależne od autoobserwacji samego podmiotu analizującego świat tekstów, uwikłane w świat ja-czytającego, $\mathrm{z}$ jego biografią i psychologią. $\mathrm{W}$ tym ujęciu poznawcza nieobiektywność jest największą humanistyczną siłą i wartością. To ja - humanum - opisuję byt, zdeterminowany moim niedoskonałym widzeniem. Oczywiście - tu zbliżamy się do pierwszego klucza tej książki, mgliście jawiącego się w podtytule - zachodzą obydwie możliwości, wszak istotą literackości i literatury jest wieloaspektowe doświadczanie sprzeczności i sprzecznościowa (to autorski pomysł Balcerzana) jest cała koncepcja, fundująca czyniony tu wywód teoretyczny. Mimo to można pokusić się o uzasadnienie celowości badań nad literackością; chodzi, mówiąc fenomenologicznie, o grunt. Grunt, czyli warunek ontyczny istnienia literatury w ogóle oraz jej sensowności. Mikel Dufrenne, francuski postheideggerowski filozof, znajduje go dla całego ludzkiego doświadczenia, nade wszystko jednak dla tego, które manifestuje się w sztuce, w Naturze (nie jest to przyroda), która, konieczna, by 
zaistniał sens, sama jest tylko i aż sensu tego warunkiem, choć jednocześnie, przeczuwając jej obecność, nie można jej poznać i określić:

Natury jako tego co pierwotne nie możemy pomyśleć, a jedynie przeczuć. Korelacja intencjonalna pomiędzy człowiekiem i światem [...], jaka pojawia się w percepcji i działaniu, zakłada korelację ontologiczną, czyniącą człowieka częścią stającej się Natury ${ }^{4}$.

Sama niepoznawalna, stwarza ona człowieka wytwarzającego po to, by dać mu się poznać, a ponieważ nie jest to możliwe - by dać się uchwycić w poznaniu intencjonalnym, jako różnica fundująca istnienie. Drogą do tego uchwycenia jest przedmiot estetyczny, mogący rozpoznać to, co przedustawne, przeddefiniowalne, co jest jednocześnie warunkiem wszelkiego istnienia i poznania. Mimo iż myśl Balcerzana nie jest blisko związana z późną fenomenologią ${ }^{5}$, wydaje mi się, że doświadczamy tu zadziwiającej koincydencji. Literackość, warunek podstawowy dla bytu estetycznego, nie jest poznawalna inaczej, niż poprzez swoją własną różnicę, nie daje się zamknąć w żadnej definicji, będąc sprzecznością; na jej gruncie zaś możliwa jest literatura. Literatura, która stworzona przez literackość, sama literackość wytwarza.

Mieszaniny półświadomych, bezkonturowych, niejasnych odczuć tajemnicy bytu sztuki literackiej - pisze Balcerzan - nie traktuję jako przeciwieństwa czy zaprzeczenia teorii, lecz - odwrotnie - widzę w niej TEORII MATERIĘ PIERWOTNĄ. W gruncie rzeczy wszyscy w niej tkwimy lub tkwiliśmy [...], bo to z tej materii pierwotnej wypływa wezwanie - do przekładu miazgi na formę, chaosu na porządek (s. 14).

I właśnie w doświadczeniu literatury czujemy obecność literackości, bez której z kolei nie byłoby literatury. To zaś odczucie, by wyjść poza książkę Balcerzana, raz jeszcze ku Dufrenne'owi (notabene autorowi Poetyki) i jego fenomenologii bytu, jest wskazaniem na fundament, na Naturę, będącą podłożem umożliwiającym wszelaki sens. „Literatura bez literackości jest nie do pomyślenia" (s. 45; też s. 12) - dodaje Balcerzan. Dlatego też - w pewnej niezgodzie z autorem Literackości - czytam te fragmenty książki, które przywołują Romana Ingardena, zwłaszcza pojmowanego jako twórcę koncepcji miejsc niedookreślenia. Jak bowiem pisze Wolfgang Iser:

„Miejsca niedookreślenia” określają zatem tylko to, czego przedmiotom literackim brak: ich wszechstronną definiowalność bądź doskonałość ich organizacji. Wobec tego Ingardenowi chodzi w dziele sztuki przede wszystkim o to, by „wyglądy nie wypełnione" przekształcić w „wypełnione”,

${ }^{4}$ P. Schollenberger, Koncepcja Natury w fenomenologii doświadczenia estetycznego Mikela Dufrenne'a, [w:] Wokót fenomenologii francuskiej, pod red. I. Lorenc, J. Migasińskiego, IFiS PAN, Warszawa 2007, s. 94.

${ }^{5}$ Zakorzeniona natomiast jest ona w myśleniu Hegla, a uściślając - w jego Fenomenologii ducha. 
a to oznacza eliminację w akcie kompozycji możliwie największej liczby „miejsc niedookreślenia" ${ }^{\prime 6}$.

Tym samym niedookreślenie jest dla Ingardena niedostatkiem dzieła, przełamywanym w wypełniającej lekturze, zmierzającej do ustabilizowania postaci utworu. Dla Isera natomiast, który używa terminu „miejsca puste", owo niewypełnienie pozwala wielokrotnie zaistnieć tekstowi, który istnieje na przecięciu ontycznym (właśnie literackości gruntującej) oraz doświadczeniowym (zatem literaturze gotowej przyjmować wciąż nowe odczytania), co owocuje sprzecznością, ale nie bezsensem. Przeciwnie - wskazuje na głębokie prawa Natury, zawsze z sobą nietożsamej i nienazywalnej. Ingarden swą koncepcją niszczy przeto to, co niepewne, mgławicowe, nieostateczne. Dlatego też jego koncepcja nie współgra z Balcerzana teorią sprzecznościową i jest złym argumentem w sprawie.

Jeśli na kilku pierwszych stronach książki Balcerzana daje się odczuć (delikatnie) pewną skrótowość, jakąś oschłość w stylu wypowiedzi, to bardzo szybko opowieść nabiera rumieńców i odbiorca jest coraz bardziej zaciekawiony dalszym ciągiem - im dalej w las, tym więcej grzybów, można by żartobliwie powiedzieć, zwłaszcza że kontynuując lekturę, mamy w swym koszyku coraz więcej prawdziwków. Chciałbym tu lakonicznie, wręcz sygnalnie, wskazać na kilka prawdziwych poruszeń poznawczych, mikrozachwycen, które stają się udziałem czytelnika otrzymującego kolejne ciekawostki, nieoczekiwane fragmenty, konteksty, historie. Wymieńmy przykładowo takie, poukrywane $\mathrm{w}$ dziele, analizy i miniinterpretacje jak: omówienie odrzuconych wariantów wersu dwudziestego Pana Tadeusza (s. 193-194); rozbiór dwóch wersji Miejsca Herberta (s. 201-202); zestawienie odmian translatorskich Sztuki poetyckiej Verlaine'a; opis historii aforyzmu: „pisarz-inżynier ludzkich dusz”, zawłaszczonego przez Stalina (s. 29); erudycyjne skomentowanie Arystotelesowskiej krytyki metafory "krzyk Kaliopy" (s. 215); interpretację poetyki paradoksu, wpisaną w słowa „metafora zaczyna się tam, gdzie kończy się przenośnia” (s. 218); przypomnienie zapoznanego utworu Mieczysława Brauna Radio czy arcyciekawą analizę doświadczenia awangardy rozrzuconej (s. 274-290). Te zaciekawienia, istotne dla adresata książki passusy, czynią studium Balcerzana tekstem podwójnym - pracą teoretyczną o literackości oraz panopticum literaturoznawczym, w którym ważne przeplata się z ciekawym, niczym dygresja czy dodatkowa linia melodyczna, wzbogacająca wykonanie.

Wracając do zasadniczej nuty tekstu, wydaje się, że głębokiego przemyślenia wymaga wskazany przez autora związek dekonstrukcji z krytyką etyczną (s. 33). Jeśli bowiem poststrukturalizm i powiązana z nim dekonstrukcja rzeczywiście odpowiadają za wzięcie w nawias badań nad literackością oraz za osłabienie roli samej literatury w ujęciach teoretycznych, to, paradoksalnie (w perspektywie późniejszych ekstracentrycznych ${ }^{7}$

${ }^{6}$ W. Iser, Apelacyjna struktura tekstów, przeł. W. Bialik, [w:] Teorie literatury XX wieku. Antologia, pod red. A. Burzyńskiej, M. P. Markowskiego, Znak, Kraków 2006, s. 79.

${ }^{7}$ Czyli zakładających, że literatura jest nade wszystko odbiciem faktów społecznych, natomiast jej immanencja i autoteliczność mają drugorzędne znaczenie. 
koncepcji postkolonialnych, feministycznych, neomarksistowskich i posthumanistycznych), zostały one (na przykład przez Christofera Norrisa, zwłaszcza dekonstrukcja) uznane za sojusznika strukturalistów w walce o tekst, o jego istotność, będącą wartością samą w sobie, i o badania immanentne. Badania tak naprawdę zmarginalizowane czy wręcz odrzucone dopiero przez rozrośnięte teorie etyczne, do których doskonale pasują słowa:

Objaśnianie faktów językowych [...] bywa, owszem, próbą przejęcia „władzy" nad tymi faktami, stając się nadinterpretacją, manipulacją, demagogią itp., ale jedynie w sytuacji, gdy w funkcji metajęzyka zostaje spożytkowany język ideologiczny (s. 39-40).

Jest to też jeden z paradoksów ujęć narratywistycznych - to, jak opowiadamy daną historię, stwarza przedmiot opowieści. Wspominam tu narratywizm, bowiem Balcerzan w kilku miejscach, zwłaszcza w części Struktury literackości, mocno podkreśla narracyjny charakter swej książki, będącej projekcją jednej z możliwych opowieści:

\section{Literaturoznawcza Księa Genesis ma dwie odmienne, zarazem mocno spokrewnione, narracje założycielskie [podkr P. G.]. Jedna każe zaczynać od LITERATURY, druga od LITERACKOŚCI. Wybór [...] staje się wymusze- niem rygoru linearnego na rzeczywistości wielowymiarowej; rzecz w tym, by linia opowieści [podkr. P. G.], deformując panoramę skomplikowanej całości, czyniła w niej najmniej szkód. W brulionowych wersjach mojej książki znajdują się próby zarysowania obu wspomnianych perspektyw [...]. Ta druga w końcu, acz nietriumfalnie, [...] przeważyła (s. 45).}

Szybko widoczny w pracy Balcerzana staje się też jej emocjonalno-poznawczo-ideowy cel, bliski również piszącemu te słowa - niezgoda na ideologiczne zawłaszczanie literatury (sztuki), które, dokonywane dla celów pozaartystycznych, niweczy tak literackość, jak literaturę; czyniąc doświadczenie sztuki jedynie narzędziem w politycznej sprawie, przy lekceważeniu jego artystycznych potencji, niszczeniu tajemnicy dzieła oraz jego wartości uniwersalnych. Sprawiając, że literatura przestaje być literaturą; literackość zaś staje się jako „cymbał brzmiący”. Słowo "autoteliczny”, będące w rozważaniach Balcerzana samoistną wartością, natychmiast przywołuje „metaforę", toteż można autorowi Literackości postawić pytanie: czy dziś moc metafory, odkryta przez szkołę praską, wciąż obowiązuje? Może przeciwnie, tym, co najważniejsze w doświadczaniu literackości, stały się dziś zjawiska ironii i alegorii (rozumianej po Benjaminowsku) oraz kategoria podmiotu, wraz ze sporem o jego istnienie bądź nieistnienie? Sama zaś metafora - chwyt chwytów, jak mawiano onegdaj - jest w słabszej kondycji, co zauważył choćby Jorge Luis Borges:

Kilkadziesiąt lat temu, w 1909 roku, argentyński poeta Leopoldo Lugones napisał, że jego zdaniem poeci stosują ciągle te same metafory i że on, Lugones, spróbuje stworzyć nowe metafory na określenie księżyca. 
Rzeczywiście udało mu się sprokurować ich setki. We wstępie do zbioru wierszy Lunario sentimental pisarz zauważył też, że każde słowo to martwa metafora ${ }^{8}$.

Zostawmy to pytanie otwartym, ważniejszy wydaje się jednak zakres stosowalności sprzecznościowej koncepcji literackości. Nie wiem, czy autor zgodziłby się z moim rozpoznaniem, ale sądzę, że jego projekt dotyczy jedynie (to zaleta!) literatury dobrej, arcydzielnej; im zaś tekst artystycznie słabszy, tym sprzeczności obserwujemy w nim mniej, albo też jest ona niezamierzonym wynikiem nieporadności pisarskiej. Tym samym, Dufrennowsko zinterpretowana tu estetyka, jej Balcerzanowski projekt okazuje swą moc w kontakcie z przedmiotem naznaczonym wartością; daleko mniej nadaje się do analizy tekstów popularnych czy banalnych. I jeśli w reklamie czy nawet ulotce promocyjnej odnajdujemy literackość, to analiza takich fenomenów nie pozwala wcale na literackości zrozumienie. Dokonany ruch krytyczny byłby $\mathrm{w}$ takim przypadku jednostronny, z literackości literatura by się nie wyłaniała, jedno nie warunkowałoby drugiego, praca byłaby daremna - ani nie poszerzylibyśmy $\mathrm{w}$ kontakcie $\mathrm{z}$ takimi utworami rozumienia tego, co literackie, ani nie znajdowalibyśmy wytłumaczenia, czy są one czy nie są literaturą; jakby coś się mgliło, ale słabo... bo i teksty słabe.

A siłą pisarstwa teoretycznego Balcerzana jest wątpienie. Figura ta chroni jego tekst, nieustannie rozmontowywany, przed dogmatyzmem:

\begin{abstract}
ARTYSTYCZNE METAMORFOZY LITERATURY - przypomina nam i sobie Balcerzan - POLEGAJĄ W DUŻEJ MIERZE - WŁAŚNIE! - NA BEZUSTANNYM ROZREGULOWYWANIU ABSTRAKCYJNEGO MODELU (s. 121).
\end{abstract}

Modelowości nieustannie zagraża schematyzacja - tym większe uznanie dla autora tekstu, który niebezpieczeństwo to widzi i minimalizuje! A równocześnie powstaje pytanie: czy w świecie sprzeczności model jest w ogóle możliwy? I na tę wątpliwość badacz znajduje odpowiedź:

HARMONIA [...] ZNAJDUJE SIĘ W PERNAMENTNYMSTANIE ZAGROŻENIA [...], [ale] dopóki czytający nie narzuca utworowi obcych znaczeń, dopóty pozostaje $\mathrm{w}$ granicach interpretacji, która zawsze, $\mathrm{w}$ mniejszym lub większym stopniu, ma charakter eksperymentalny (s. 122-123).

Model to po prostu literaturoznawczy eksperyment!

Najbardziej osobisty - niemal jak wyznanie naukowej wiary - jest rozdział poświęcony strukturalizmowi (Strukturalizm powrotny). Czy rzeczywiście paradygmat strukturalny nadal ma moce interpretacyjne i szansę na swą nową odsłonę? Autor uważa tę możliwość za racjonalną. Jego książka chce pokazać żywotność tej formy myśli w podstrukturalnym świecie;

${ }^{8}$ Zob. J. L. Borges, Sztuka poetycka, przeł. A. Sobol-Jurczykowski, „Przegląd Filozoficzno-Literacki" 2005 nr 3-4, s. 25-26. 
niewątpliwie znużenie krytykami etycznymi i obserwowany coraz wyrazistszy powrót do tekstów, wraz z koncepcją wolnego czytania, sprawiają, że propozycja strukturalna winna być przemyślana ponownie, popoststrukturalnie. Z uwzględnieniem neurobiologii i neurofizyki z jednej strony, narratywizmu $\mathrm{z}$ drugiej. $\mathrm{Z}$ mniejszym nastawieniem na model, większym na eksperyment. Wszystkie zresztą argumenty za przedstawia najlepiej omawiana Literackość.

Zasadnicza i najistotniejsza część refleksji Balcerzana (obok wskazanej już poetyki miniatur interpretacyjnych oraz pytań o strukturalizm) mieści się w rozdziałach otwierającym i zamykającym. Pierwszy analizuje struktury zawierające w sobie literackość, ostatni (Sobowtóry i refleksy literackości w uniwersum) tworzy model uniwersalny, przenoszący literackość z konkretnych empirii i praktyk na całość wielkiego doświadczenia artystycznego. Ogarnia on czas, przestrzeń, rodzaj i gatunek w jednej, scalającej opowieści teoretycznej.

Pisanie o modelach to ciężki trud... dla czytelnika. Terminy się mnożą, uważność wzrasta, ale i ulega rozproszeniu, pojedyncze analizy zaczynają udawać całość, ale czy już są całością? Dlatego warto z uznaniem podkreślić metodę wykładu stosowaną przez Balcerzana: dowcipny cytat, przeplatanie wywodu interpretacją, anegdota. Nie są to jedynie chwyty uatrakcyjniające; przeciwnie, literatura i poprzez nią literackość, są dzięki takiej narracji stale uobecniane i intencjonalnie uchwytne dla czytającego, podskórnie wspierają naukowy wywód. Są obecne w książce nie tylko jako przedmiot opisu, ale jako dana namacalnie naoczność tekstu. Także głos autora kierowany ku czytelnikowi - sam sprawdź, czy mam rację. Jest to zresztą jedyny sposób, by niemożliwe uczynić możliwym, bowiem przecież literackość natychmiast konotuje szereg „antysłów”, którym sama teoria, bez pomocy literatury, sprostać nie może; słów takich, jak przywoływane częstokroć w szeregu gradacyjnym: „NIEPOZNAWALNE, NIEWYOBRAŻALNE, NIEPRZEKŁADALNE, NIEWYRAŻALNE” (s. 63). "Chciałbym opisać najprostsze wzruszenie - pisze Balcerzan-Herbert - ale nie jest to widać możliwe"; no, chyba że z pomocą poezji. Tym samym autor znalazł taki tryb mowy, w którym niemożliwe stało się możliwym. A jego praca jest zarazem wielką pochwałą (filologicznego i nie tylko) czytania. Zaś słowo „awaria” (komunikacyjna) jest słuszne, o ile komunikacyjność jest naszym jedynym lekturowym celem. Inne powody skłaniające nas do czytania, wcale niezgorsze, mogą wręcz pożądać niekomunikatywności, jak choćby w doświadczeniu kabalistycznym.

Na koniec chciałbym wskazać dwa fragmenty książki Balcerzana, które budzą chęć polemiki. Pragnienie dyskusji, najlepiej z autorem, nie z jego sygnaturą. Pierwszy - czy rzeczywiście niewyrażalne da się sprowadzić do niewyrażonego? Wszak są doświadczenia, w obliczu których język jest jedynie pełen niemocy; a nawet jeśli w kolejnych próbach zbliża się do uchwycenia sedna, to najczęściej jest to kolejna iluzja, samo zaś zbliżanie się jest zaciemnieniem i oddalaniem. Po drugie, warto spytać, czy zawsze możemy myśleć obrazami? Nie chodzi mi tu o wykluczonych przez Balcerzana motoryków; przeciwnie, raczej o ustalenie, jakie obrazy wzbudzi w sobie, przykładowo, 
czytelnik najkrótszej powieści awangardowej ${ }^{9}$ czy na przykład Wieczności Białoszewskiego $?^{10}$ Jak bowiem ujrzeć pustkę, zwłaszcza pustkę absolutną, w której nade wszystko nie ma samego obserwatora? To już jednak inny typ rozważań, inspirowany tą zajmującą pracą. Literackość natomiast - nie wahajmy się tego napisać - jest publikacją teoretycznie konieczną, jest książką wyznaczającą nowe obszary na literaturoznawczej mapie.

\section{B I B LIOGRAFIA}

Balcerzan E., Literackość. Modele, gradacje, eksperymenty, WN UMK, Toruń 2013.

Borges J.L., Sztuka poetycka, przeł. A. Sobol-Jurczykowski, „Przegląd Filozoficzno-Literacki" 2005, nr 3-4.

Culler J., Literatura w teorii, przeł. M. Maryl, Universitas, Kraków 2013.

Culler J., Teoria literatury, przeł. M. Bassaj, Prószyński i Spółka, Warszawa 1998.

Dufrenne M., Zmystowa wrażliwość wytwórcza, przeł. I. Lorenc, [w:] Fenomenologia francuska, pod red. I. Lorenc, J. Migasińskiego, IFiS PAN, Warszawa 2006.

Iser W., Apelacyjna struktura tekstów, przeł. W. Bialik, [w:] Teorie literatury XX wieku. Antologia, pod red. A. Burzyńskiej, M. P. Markowskiego, Znak, Kraków 2006.

Schollenberger P., Koncepcja Natury w fenomenologii doświadczenia estetycznego Mikela Dufrenne'a, [w:] Wokót fenomenologii francuskiej, pod red. I. Lorenc, J. Migasińskiego, IFiS PAN, Warszawa 2007.

\section{STRESZCZENIE}

Recenzja pracy Edwarda Balcerzana poświęconej literackości dotyczy ważnych kwestii współczesnej teorii literatury: na ile pewne kategorie teoretyczne wciąż

${ }^{9}$ Najkrótszą powieść awangardową napisał Andrzej Tuziak: „Czytam opowiadanie, na które składa się zdanie mówiące o tym, że czytam opowiadanie składające się z osiemnastu wyrazów", [w:] tenże, Księga zaklęć, Fa art, Bytom 1996.

${ }^{10} \mathrm{M}$. Białoszewski, A to i tak taka wieczność, [online] http://ewiersze.net/bialoszewski-miron-a-to-i-tak-taka-wiecznosc,42776/, (dostęp: 1.10.2016):

A to i tak taka wieczność

A nawet jeśli nie taka

a wieczna wieczność

to i ona ma podszewkę

i ona się wywróci

i zejdzie 
mają rację bytu, czy możliwa jest nowa odsłona paradygmatu strukturalistycznego, jakie są dziś wartości myślenia modelowego?

\section{Słowa kluczowe}

Edward Balcerzan, strukturalizm, dekonstrukcja, literackość, teoria literatury, postfenomenologia

\section{S U M M A RY}

\section{Impossible as necessary, that is non-certainty in literary studies}

The review of Edward Balcerzan's work devoted to literatureness focuses on some significant issues within the modern theory of literature: the raison d'etre of certain theoretical categories, the possibility of redefining the structuralist paradigm, and contemporary values of model thinking.

\section{Keywords}

Edward Balcerzan, structuralism, deconstruction, literatureness, theory of literature, postphenomenology 